\title{
FOCUS: DISTONIC IONS: EDITORIAL
}

\section{Distonic Ions: Editorial}

$\mathrm{W}$

elcome to this JASMS focus issue on Distonic Ions. The idea to run this focus arose from the enthusiastic reception for the "Distonic Radical Ions: Fundamentals and Applications" session of the 60th ASMS Conference held in Vancouver May 20-24, 2012. This session, co-chaired by Professors Michael Siu and Richard O'Hair, was comprised of six presentations spanning a range of topics. Interest in the subject of distonic ions, which was one of the "hot" subjects in mass spectrometry and ion chemistry 25 or more years ago, has seen a renaissance owing in part to the use of electron capture dissociation (ECD) and electron-transfer dissociation (ETD), two processes that convert closed-shell cations into radical cations.

The term "Distonic Radical Cation" was coined by Professor Leo Radom and his co-workers in a landmark paper published in the Journal of the American Chemical Society [1] and was defined as "distonic (from the Greek " $\delta \iota \varepsilon \sigma \tau \varpi \sigma "$ (diestos) and Latin distans meaning separate) radical cations in which the charge and radical sites are separated (e.g., ${ }^{\circ} \mathrm{CH}_{2} \mathrm{CH}_{2} \mathrm{OH}_{2}{ }^{+}$)." The term was ultimately endorsed by IUPAC [2]. The work reported in Radom's paper was carried out by his research group 30 years ago (Figure 1) and generated much interest in the mass spectrometry community. Distonic ions, which are quite stable, were found to be common intermediates in EI/MS and ion-molecule reactions of radical cations. As noted in Hammerum's early review [3], distonic ions have an even longer history than 30 years in mass spectrometry, dating back to studies from the 1970s [4-8].

Given the editor-in-chief's early contributions to this area, some reminiscences of those early days of ion chemistry may be of interest to you. One of the first papers [4] by Jaffe, Billets, and Kaplan described that dialkyl- $N$-nitrosamines radical cations acted as gas-phase acids presumably because an intramolecular proton transfer had occurred to produce $\mathrm{a}-\mathrm{N}=$ $\mathrm{OH}^{+}$along with a free radical site located remotely from the charge site. The EI-induced fragmentation to lose $\mathrm{OH}$ is consistent with the hypothesis. This is one of the first examples where evidence was presented that an unusual species with localized charge and spin did exist.

In our own work [6] reported 1 year later, we produced a species, $\cdot \mathrm{CH}_{2}-\mathrm{NH}_{3}{ }^{+}$in an ion-molecule reaction between the cyclopropane radical cation and neutral ammonia in a drift-cell ion cyclotron resonance mass spectrometer, the predecessor of today's FTICR instrument. We knew the product was unusual because it was more acidic than the conventional isomer, $\mathrm{CH}_{3} \mathrm{NH}_{2}{ }^{+\bullet}$. Details of this process were revealed in a 1972 sequel paper that represented one of my first independent efforts as an assistant professor [7]. Unfortunately, we were not sufficiently clever to name these species to be "distonic" and to

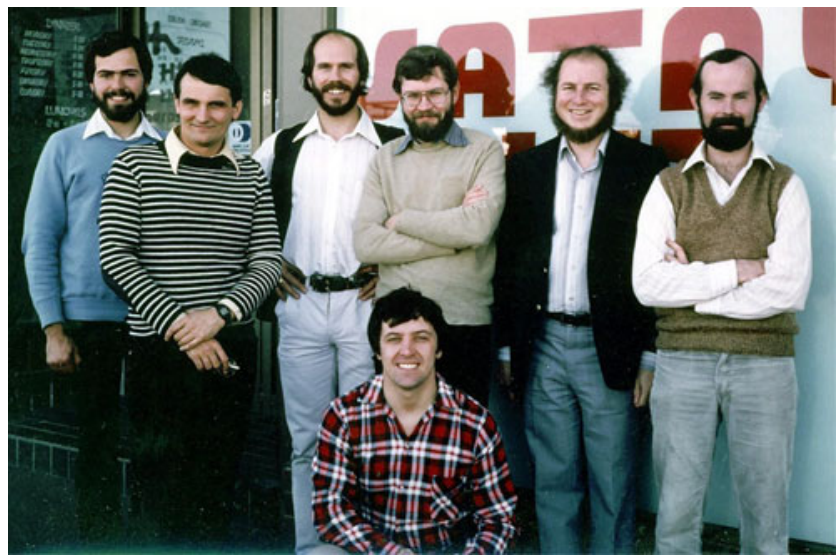

Figure 1. Radom's group from 1983, including the key authors from the Journal of the American Chemical Society paper [1]. Brian Yates is at far left, Willem Bouma is third from left, and Leo Radom is second from right. (Image courtesy of Professor Leo Radom)

realize their general importance in ion chemistry. That awaited the work of Leo Radom. Nevertheless, we hope the reader will understand our enthusiasm for this subject.

Although interest in distonic ions decreased over the years as the subject of mass spectrometry moved into biochemistry, biology, and the various "omics," the subject has been the topic of 81 papers and two reviews since 1980 (Scopus search). Furthermore, there have been many presentations at ASMS conferences over the years on the subject of distonic ions.

The articles presented in this Focus issue nicely highlight the current range of interest in distonic ions and can be classified into two main categories: (1) the chemistry of "small molecule" distonic ions, and (2) distonic ions derived from biomolecules.

Professor Hilka Kenttamaa and her group have been actively pursuing the reactivity of distonic ions and related biradical and triradical ions for the past 2 decades, so it is fitting to start with an article that describes both gas-phase and condensed-phase work on isomeric distonic ions of the pyridine radical cation (Widjaja, Jin, Nash, and Kenttämaa). Other papers dealing with "small" distonic ions include: the use of UV-vis spectroscopy to determine the structure of the product from the reaction of $\mathrm{NO}_{2}$ to carbon-centered radicals (Kirk, Trevitt, Blanksby); the use of distonic ions to model a key combustion intermediate ( $\mathrm{Li}, \mathrm{Lam}$, Khairallah, White, O'Hair, da Silva); some novel distonic ions derived from oxidized transition metal-thiolate complexes $(\mathrm{Lu}$, Campbell, Chauhan, Grapperhaus, Chen).

The papers on biological distonic ions include: A Consideration of the Isomers of the Radical Cations of Tryptophan (Piatkivskyi, Osburn, Jaderberg, Grzetic, Steill, Oomens, Zhao, Lau, Verkerk, Hopkinson, Siu, and Ryzhov); Radical Migrations in Peptides (Zhang and Julian); The Chemistry of Sulfur- 
Based Radicals Derived from the Amino Acid Side Chains of Cysteine (Tan and Xia) and Methionine (Lau, Lo, Zhao, Siu, and Hopkinson); and The Mechanisms of Phosphate Cleavage in Radical Cations of a Phosphopeptide Model System (Quan, Hao, Song, Siu, and Chu).

As these Focus articles hopefully show, distonic ions remain important species in mass spectrometry, and we predict that interest in them will grow again. Thus, we hope you will enjoy this focus section and find some application of the concept in your own research.

\section{References}

1. Yates, B.F., Bouma, W.J., Radom, L.: Detection of the prototype phosphonium $\left(\mathrm{CH}_{2} \mathrm{PH}_{3}\right)$, sulfonium $\left(\mathrm{CH}_{2} \mathrm{SH}_{2}\right)$, and chloronium $\left(\mathrm{CH}_{2} \mathrm{ClH}\right)$ ylides by neutralization-reionization mass spectrometry: a theoretical prediction. J. Am. Chem. Soc. 106, 5805-5808 (1984)

2. Available at: http://goldbook.iupac.org/D01809.html. Accessed 4 March 2013

3. Hammerum, S.: Distonic radical cations in gaseous and condensed phase. Mass Spectrom. Rev. 7, 123-202 (1988)

4. Jaffe, H.H., Billets, S., Kaplan, F.: Rearrangements of molecular ions of dialkyl-N-nitrosamines. J. Am. Chem. Soc. 92, 6964-6965 (1970)

5. Jaffe, H.H., Billets, S.: Electrical effect of free-radical groups. J. Am. Chem. Soc. 92, 6965 (1970)
6. McLafferty, F.W., Gross, M.L.: Identification of $\mathrm{C}_{3} \mathrm{H}_{6}^{+}{ }^{+}$structural isomers by ion cyclotron resonance spectroscopy. J. Am. Chem. Soc. 93, 1267-1268 (1971)

7. Gross, M.L.: An ion cyclotron resonance study of the structure of $\mathrm{C}_{3} \mathrm{H}_{6}^{+\bullet}$ and the mechanism of its reaction with ammonia. J. Am. Chem. Soc. 94, 3744-3748 (1972)

8. Morton, T.H., Beauchamp, J.L.: Chain-length effects upon the interaction of remote functional groups. Low energy electron impact mas spectra of $\alpha, \omega$-dialkoxyalkanes examined by ion cyclotron resonance spectroscopy. J. Am. Chem. Soc. 97, 2355-2362 (1975)

Richard A. J. O'Hair

Associate Editor, JASMS

School of Chemistry

Bio21 Institute of Molecular Science and Biotechnology

$A R C$ Centre of Excellence for Free Radical Chemistry and Biotechnology

The University of Melbourne,

Victoria 3010, Australia

e-mail: rohair@unimelb.edu.au

\section{Michael L. Gross}

Editor-in-Chief, JASMS

Department of Chemistry

Washington University in St. Louis

St. Louis, MO, USA 